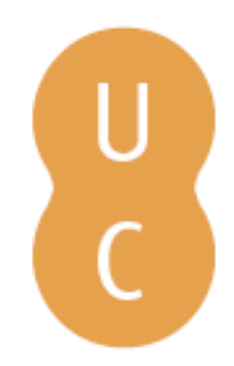

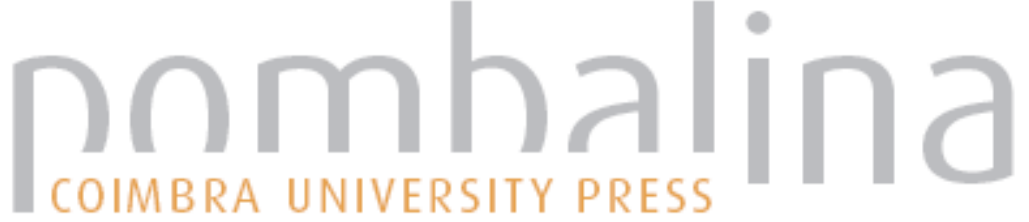

\section{Prologue: irreligiosity in fifth-century Athens}

\author{
Autor(es): Domingo Gygax, M.
}

Publicado por: Imprensa da Universidade de Coimbra

URL

persistente: URI:http://hdl.handle.net/10316.2/44016

DOI: $\quad$ DOI:https://doi.org/10.14195/978-989-26-1598-1_1

Accessed : $\quad$ 26-Apr-2023 15:25:41

A navegação consulta e descarregamento dos títulos inseridos nas Bibliotecas Digitais UC Digitalis, UC Pombalina e UC Impactum, pressupõem a aceitação plena e sem reservas dos Termos e Condições de Uso destas Bibliotecas Digitais, disponíveis em https://digitalis.uc.pt/pt-pt/termos.

Conforme exposto nos referidos Termos e Condições de Uso, o descarregamento de títulos de acesso restrito requer uma licença válida de autorização devendo o utilizador aceder ao(s) documento(s) a partir de um endereço de IP da instituição detentora da supramencionada licença.

Ao utilizador é apenas permitido o descarregamento para uso pessoal, pelo que o emprego do(s) título(s) descarregado(s) para outro fim, designadamente comercial, carece de autorização do respetivo autor ou editor da obra.

Na medida em que todas as obras da UC Digitalis se encontram protegidas pelo Código do Direito de Autor e Direitos Conexos e demais legislação aplicável, toda a cópia, parcial ou total, deste documento, nos casos em que é legalmente admitida, deverá conter ou fazer-se acompanhar por este aviso.

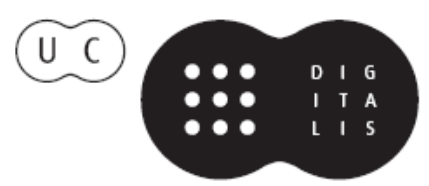




\section{Irreligiosidad y}

Literatura en la Atenas Clásica

V.M. Ramón Palerm, G. Sopeña Genzor, A.C. Vicente Sánchez (eds.)

IMPRENSA DA UNIVERSIDADE DE COIMBRA 


\section{Prologue Irreligiosity in Fifth-Century Athens}

M. Domingo Gygax Princeton University

Some sociologists maintain that a correlation exists between economic prosperity and irreligiosity. If so, classical Athens would seem to be one of the best pre-modern societies in which to look for the latter. Recent research on economic history - particularly work by Josiah Ober- has concluded that the world of the archaic and classical Greek poleis was considerably wealthier than scholars have traditionally imagined. Indeed, classical Athens seems to have been one of the most prosperous communities in pre-modern history. Personal income was high, wealth was distributed relatively evenly, and a significant portion of the population lived considerably above subsistence level. Material conditions aside, classical Athens offered an intellectual atmosphere especially suited to the challenging of religious ideas. The political and judicial systems produced a culture of debate among citizens both at the polis level and in the demes, a custom of deliberation that the Funeral Oration of Thucydides' Pericles describes as one of the most distinctive features of the Athenians in comparison to other Greeks. In the fifth century, the period on which this volume focuses, this deliberative culture, together with the city's wealth and its position as the capital of an empire, drew numerous intellectuals from other parts of the Greek world, particularly Ionia and Sicily, to Athens, bringing them into contact with local thinkers. In the tradition of the pre-Socratic philosophers, these individuals asked about the primary material from which the universe derived, sought human causes to explain historical events, attempted to discover scientific responses to diseases, and even transformed the art of argument into the science of rhetoric. It was thus almost inevitable that in such a climate traditional religious beliefs would be challenged.

But what kind of challenge was it, and what do we mean by "irreligiosity"? In principle, irreligiosity is behavior or ideas perceived (or, if they fail to be noticed, capable of being perceived) by a community as questioning its religious practices and/or religious views. In the ancient Greek context, highly diverse and even conflicting attitudes lay behind this definition. These ranged from atheism (outright denial of the existence of the divine) to its opposite, a monotheistic "perfection" of belief in divinity, and included the polytheism of those who believed in the gods to the point of defying them. Many Greek gods were so human in appearance and behavior, so close to human beings (by whom they could even have descendants), while some human beings were so near to gods (in the sense that they were revered after death as quasi-divine), that it comes 
as no surprise that mortals occasionally tried to rival divinities, as if they were Homeric heroes. But such defiance could be judged offensive (irreligious) by the community.

Hecataeus' belief that many mythological stories were false and Xenophanes' claim that the anthropomorphic gods were a human invention were also irreligious. Xenophanes at least speaks of gods (in the plural, although one is above the others), but Thales, Anaximander and Anaximenes seem to have a single god in mind. As has been pointed out, while Thales probably believed in a rational god who created the universe, for Anaximander and Anaximenes the word "god" may have been no more than a metaphorical way of referring to nature. Hippo of Samos, in any case, could be considered an atheist in the modern sense of the word, if his explanation of the world in fact involved nothing but matter.

Greek religiosity - that is to say, how religion was understood and lived in ancient Greece-offered conditions relatively prone to the development of atheism, agnosticism and forms of religiosity alternative to the traditional one. Polytheism, especially polytheism of the Greek type, in which there were numerous local manifestations of the same god, is by its nature open to considerable religious diversity. Greek polytheism had the ability to incorporate new gods and was at ease in coexisting with those it could not integrate. Nor did Greece have a revealed religion or a sacred literature, but only a mythological tradition with competing and contradictory versions of stories open to multiple interpretations. There was thus no orthodoxy and no guardians of orthodoxy or "church".

Paradoxically, the same conditions that favored irreligiosity made the phenomenon less visible and so more difficult for us to track. The scarcity of state repression on religious grounds, and the lack of clashes between individuals and communities over religious ideas, tended to minimize the irreligious behaviors often recorded in less tolerant societies. At the same time, the absence of religious orthodoxy must have contributed to lessening the need to protest against the dominant religion by those who did not share it. When religion is not imposed, there is less inclination to openly disagree with it. As noted above, however, Athens in the second half of the fifth century was a special situation, and the debate regarding traditional religion among intellectuals seems to have reached extremes that led the polis to intervene. The gods ensured the welfare of the polis, after all, and it was imperative not to anger them, particularly in times of war. The Diopeithes decree of the 430s BC "providing for the public impeachment of those who did not believe in gods" (Plu. Per. 32. 2) may not be historical, nor it is clear whether Diagoras "the Atheist" was prosecuted for atheism or for profanation of the Eleusinian Mysteries, while the authenticity of the impiety trials of Anaxagoras, Protagoras and Euripides is open to serious doubt. It nonetheless seems clear, as Tim Whitmarsh has shown, that in the second half of the fifth century there was repression of those who disputed the 
existence of the traditional gods. A change appears to have occurred, in the sense that individuals were now prosecuted for irreligious words and not just for irreligious deeds. In $399 \mathrm{BC}$ Socrates was put on trial not for impious actions but for impious beliefs and speech (P1. Ap. 24 b-c; X. Mem. 1. 1. 1). The religious dissidents certainly included atheists, although the lists of them provided by ancient sources are controversial. David Sedley is probably right that there were many more atheists than is usually supposed and that, if we have only a few names, that is because others censored themselves out of fear of the consequences of publicly announcing their beliefs.

Book 10 of Plato's Laws (from ca. $350 \mathrm{BC}$ ) is especially illuminating in this regard. In the dialogue, which takes place on the island of Crete, an anonymous Athenian tells the Cretan Clinias that atheism is neither new nor exceptional: "Neither you by yourself nor yet your friends are the first and foremost to adopt this opinion regarding the gods; rather, is it true that people who suffer from this disease are always springing up, in greater or lesser numbers" (Pl. Lg. 888 b, tr. Bury [adapted]). From this and other passages in Book 10, we can follow Sedley in deducing that there were more atheists in Athens than elsewhere, that the situation went back at least to the final third of the fifth century, and that texts denying the existence of the gods were in circulation at that time. The famous phrase of Protagoras (written before ca. 420 BC), "concerning the gods, I am unable to know whether they exist or not, or what form they have" (DK 80 B 4), is not only evidence of agnosticism (or the beginning of an atheistic argument) but perhaps also a reflection of an earlier debate regarding the existence of gods.

Interestingly, the debate was not limited to intellectual circles, as is indicated by a fragment of a fifth-century tragedy or satyr play written by Critias, Euripides or an anonymous author-the Sisyphus fragment-in which religion is explained as a fiction introduced to control people and maintain social order. According to this fragment, punitive laws were invented first, but since they proved insufficient, a clever man "introduced belief in gods-that there exists a divine power flourishing with indestructible life and hearing and seeing with a mind, and both thinking and paying attention to these matters, and having a godlike nature that will hear everything said among mortals and will be able to see everything that is done" (Critias $\operatorname{Tr} G F 43$ F $19=$ DK 88 B 25, tr. Collard and Cropp [adapted]). The modernity of this thesis may surprise us, but the author of the Sisyphus fragment is not the only person in fifth-century Athens attempting to offer socio-historical explanations for the emergence of religion, for Prodicus' ideas about how human beings invented gods also deserve attention.

The present volume does not attempt to answer larger questions such as the significance of atheism in fifth-century Athens, but merely aims to provide the material for doing so. It begins with a discussion of modern literature on Greek irreligiosity in general, and of fifth-century Athens in particular, covering publications from 1991 to 2016, the period after Marek Winiarczyk's Bibliographie 
zum Antiken Atheismus. 17. Jabrhundert-1990 (1994). The main section then analyzes a selection of texts divided into five categories: tragedy (Aeschylus, Sophocles, Euripides), satyr drama (Euripides), comedy (Aristophanes), oratory (Antiphon, Andocides), and historiography (Herodotus, Thucydides). The editors have chosen to exclude texts attributed to sophists because they have been transmitted indirectly and do not belong to the corpus of genuine fifth-century material. The volume offers the text of each passage in Greek (with an indication of the edition, variae lectiones and loci similes), as well as a translation into Spanish by the author in charge of the section (except in the case of Herodotus, for whom Carlos Schrader's 1977-1989 translation has been used), and provides commentary on each passage. Vicente Ramón Palerm has been in charge of the bibliographical essay, Aristophanes and the orators, Ana Vicente Sánchez of tragedy and satyr play, and Gabriel Sopeña Genzor of the historians. The volume concludes with a brief essay considering how the question of irreligiosity in Athens was treated from Plato to Plutarch by Françoise Frazier, to whose memory this book is dedicated. 